\title{
Purification and Properties of Diaminopimelate Decarboxylase from Escherichia coli
}

\author{
BY P. J. WHITE AND BRIDGET KELLY \\ Twyford Laboratories, Twyford Abbey Road, London, N.W.10
}

(Received 16 October 1964)

\begin{abstract}
1. Diaminopimelate decarboxylase from a soluble extract of Escherichia coli A.T.C.C. 9637 was purified 200 -fold by precipitation of nucleic acids, fractionation with acetone and then with ammonium sulphate, adsorption on calcium phosphate gel and chromatography on DEAE-cellulose or DEAE-Sephadex. 2. The purified enzyme showed only one component in the ultracentrifuge, with a sedimentation coefficient of $5 \cdot 4 \mathrm{~s}$. One major peak and three much smaller peaks were observed on electrophoresis of the enzyme at pH 8.9. 3. The mol.wt. of the enzyme was approx. 200000 . The catalytic constant was $2000 \mathrm{~mol}$. of meso-diaminopimelic acid decomposed $/ \mathrm{min}$. $/ \mathrm{mol}$. of enzyme, at $37^{\circ}$. The relative rates of decarboxylation at $25^{\circ}, 37^{\circ}$ and $45^{\circ}$ were $0 \cdot 17: 1 \cdot 0: 1 \cdot 6$. At $37^{\circ}$ the Michaelis constant was $1 \cdot 7 \mathrm{~mm}$ and the optimum pH was $6 \cdot 7-6 \cdot 8$. 4. There was an excess of acidic amino acids over basic amino acids in the enzyme, which was bound only on basic cellulose derivatives at pH 6.8. 5. The enzyme had an absolute requirement for pyridoxal phosphate as a cofactor; no other derivative of pyridoxine had activity. A thiol compound (of which 2,3-dimercaptopropan-1-ol was the most effective) was also needed as an activator. 6. In the presence of 2,3-dimercaptopropan-1-ol (1 mM), heavy-metal ions $\left(\mathrm{Cu}^{2+}, \mathrm{Hg}^{2+}\right)$ did not inhibit the enzyme, but there was inhibition by several amino acids with analogous structures to diaminopimelate, generally at high concentrations relative to the substrate. Penicillamine was inhibitory at relatively low concentrations; its action was prevented by pyridoxal phosphate.
\end{abstract}

Diaminopimelate decarboxylase (EC 4.1.1.20; meso-2,6-diaminopimelate carboxy-lyase) is a bacterial enzyme that specifically decarboxylates the meso-isomer of diaminopimelic acid to yield Llysine. Previous work on the preparation and properties of this enzyme has been reviewed by Work (1962). Previously, it was partially purified from acetone-dried Aerobacter aerogenes, with the chief object of removing diaminopimelate epimerase (racemase) and lysine decarboxylase (Dewey, Hoare \& Work, 1954; Hoare \& Work, 1955). Evidence was obtained that pyridoxal phosphate was the coenzyme, although a completely inactive apoenzyme was not obtained. Heavy-metal ions or other thiol-binding reagents inhibited the enzyme, and such inhibitions could be prevented by glutathione or other thiols. The DD- and LL-isomers of diaminopimelic acid were not attacked by the partially purified enzyme; of the homologous series of diaminodicarboxylic acids :

$$
\mathrm{HO}_{2} \mathrm{C} \cdot \mathrm{CH}\left(\mathrm{NH}_{2}\right) \cdot\left[\mathrm{CH}_{2}\right]_{n} \cdot \mathrm{CH}\left(\mathrm{NH}_{2}\right) \cdot \mathrm{CO}_{2} \mathrm{H}
$$

where $n$ was 0 to 8 , only meso-diaminopimelic acid was attacked. In all these studies, the activity of diaminopimelate decarboxylase was determined from the initial rate of evolution of carbon dioxide. Since at $\mathrm{pH} 6 \cdot 8$, the optimum for this enzyme, there is considerable retention of carbon dioxide in solution, the enzymic activity measured manometrically was only about three-quarters of the true rate.

In the present work the purification of diaminopimelate decarboxylase has been carried further, and more of its properties have been studied. After a survey of the occurrence of the enzyme in several species (White, Kelly, Suffling \& Work, 1964), Escherichia coli was chosen as a source. Use of this species was advantageous because the organisms had a relatively high enzymic activity, and the apoenzyme and coenzyme were already completely dissociated in a soluble extract of the organisms.

\section{METHODS}

Growth and harvesting of organisms. E. coli American Type Culture Collection no. 9637 was maintained on slopes of nutrient-agar (Oxoid) grown at $37^{\circ}$. Stock cultures were transferred monthly and stored at $2^{\circ}$.

Organisms were grown in 21 . conical flasks at $37^{\circ}$ in the medium described by Davis \& Mingioli (1950), modified 
by autoclaving the glucose $(0 \cdot 2 \%)$ in the medium for $7 \mathrm{~min}$. at $115^{\circ}$. In some cases a sub-inhibitory concentration of $S$-(2-aminoethyl)cysteine hydrochloride $(0.5 \mathrm{mg}$./1.) was added to the medium before autoclaving. Each flask, containing $250 \mathrm{ml}$. of medium, was inoculated with $0.5 \mathrm{ml}$. of a suspension in sterile water of organisms (about $0.5 \mathrm{mg}$. dry wt./ml.) from an overnight culture on nutrient-agar. The flasks were incubated at $37^{\circ}$ while shaken mechanically at 200 gyrations/min. (model VS Gyro-rotatory shaker; New Brunswick Scientific Co., New Brunswick, N.J., U.S.A.). Usually 3-61. of culture was grown at one time. Organisms were harvested when growth had almost reached the end of the exponential phase (15-18hr.). Occasionally, larger quantities of organisms were grown at $37^{\circ}$ in the same medium (with glucose autoclaved separately) in a continuous-culture apparatus. The culture was withdrawn from the apparatus while the organisms were in the exponential phase of growth (about 0.5 mg. dry wt. of organisms/ml.), at a rate of about $500 \mathrm{ml}$. $/ \mathrm{hr}$. The culture was collected in a receiver kept at $2^{\circ}$ before harvesting the organisms by centrifuging.

Harvested organisms were washed twice in $0.02 \mathrm{M}$-phosphate buffer, pH6.8, by using for each wash a volume of buffer about one-quarter that of the culture. The washed organisms were resuspended in $0 \cdot 1 \mathrm{M}$-phosphate buffer, pH 6.8, containing BAL* $(0.1 \mathrm{~mm})$; this buffer was made by mixing equal volumes of $0.1 \mathrm{M}-\mathrm{Na}_{2} \mathrm{HPO}_{4}$ and $0.1 \mathrm{M}$ $\mathrm{NaH}_{2} \mathrm{PO}_{4}$. About $15 \mathrm{ml}$. of buffer was used to resuspend the organisms from 11 . of culture, which gave about $30 \mathrm{mg}$. dry wt. of organisms $/ \mathrm{ml}$. Buffers, growth medium and all other solutions were made up in glass-distilled water.

Purification of diaminopimelate decarboxylase. Phosphate buffer, $\mathrm{pH} 6 \cdot 8$, at various concentrations, was used throughout the purification, always with $0 \cdot 1 \mathrm{~m}$ M-BAL present. All steps were done at $2^{\circ}$, unless stated otherwise.

Preparation of extract. Washed organisms suspended in $0 \cdot 1 \mathrm{~m}$-phosphate buffer were broken by passage at $4000 \mathrm{lb}$./ in. ${ }^{2}$ through the press described by Milner, Lawrence \& French (1950). The debris was removed by centrifuging at $20000 \mathrm{~g}$ for $20 \mathrm{~min}$. The supernatant liquid (extract) was diluted with $0.1 \mathrm{M}$-phosphate buffer to give about $20 \mathrm{mg}$. of protein $/ \mathrm{ml}$.

Precipitation of nucleic acids. To the extract were added, with mixing, $1 \%(\mathrm{w} / \mathrm{v})$ protamine sulphate in $0 \cdot 1 \mathrm{M}-$ phosphate buffer $(0.1 \mathrm{ml} . / 5 \mathrm{ml}$. of extract) followed immediately by $25 \%(\mathrm{w} / \mathrm{v})$ streptomycin sulphate in $0.1 \mathrm{M}$-phosphate buffer $(0.6 \mathrm{ml} . / 5 \mathrm{ml}$. of extract). The precipitate was left to settle for $2 \mathrm{hr}$. before removal by centrifuging. The supernatant liquid was kept overnight, and any further precipitate was also removed.

Acetone fractionation. The supernatant liquid from the previous step was cooled in an ice-salt mixture to the point of freezing, and acetone at $-15^{\circ}$ was added slowly with continuous stirring, to give $40 \%(v / v)$ acetone. The precipitate was left to settle at $-15^{\circ}$ for $1 \mathrm{hr}$., then was removed by centrifuging and discarded. The supernatant liquid was cooled to $-15^{\circ}$ and more acetone at $-15^{\circ}$ was added to give $50 \%(\mathrm{v} / \mathrm{v})$ acetone. The precipitate was left to settle at $-15^{\circ}$ for $1 \mathrm{hr}$. then was removed by centrifuging, and was immediately redissolved in $0.01 \mathrm{M}$-phosphate buffer (1ml./ml. of original extract). The diaminopimelate decarboxylase was not always completely precipitated

\footnotetext{
* Abbreviation: BAL, 2,3-dimercaptopropan-1-ol.
}

between 40 and $50 \%$ acetone, and a small trial experiment was usually done for each batch of enzyme to find the best concentrations of acetone for fractionation.

Precipitation with ammonium sulphate. Solid ammonium sulphate was added to the redissolved precipitate from the previous step, to give $50 \%$ saturation. The precipitate was left to settle for $1 \mathrm{hr}$., then was removed by centrifuging and redissolved usually in $0.01 \mathrm{M}$-phosphate buffer $(0.5 \mathrm{ml}$./ $\mathrm{ml}$. of original extract). The solution was dialysed overnight against $0.01 \mathrm{~m}$-phosphate buffer containing BAL $(0 \cdot 1 \mathrm{mM})$ (about 20 times the volume of the enzyme solution) to remove ammonium sulphate. After dialysis a slight precipitate was removed from the enzyme solution by centrifuging. To avoid loss of enzymic activity during this and subsequent dialyses it was necessary to use dialysis tubing (Visking) that had been washed in several changes of water containing EDTA (1mM). Buffers used for dialysis always contained $\mathrm{BAL}(0 \cdot 1 \mathrm{~mm})$.

Adsorption on calcium phosphate gel. In some experiments the precipitate from ammonium sulphate was redissolved in $0.001 \mathrm{~m}$-phosphate buffer $(0.5 \mathrm{ml} . / \mathrm{ml}$. of original extract). This solution, without dialysis, was added to calcium phosphate gel (about $80 \mathrm{mg}$. dry wt. of gel $/ \mathrm{ml}$. of enzyme solution) in a centrifuge tube and stirred during $15 \mathrm{~min}$. The gel was centrifuged and the supernatant liquid was mixed with a second portion of gel as before. The two lots of gel were combined and eluted with buffer $(15 \mathrm{ml}$./g. of gel) at increasing concentrations: $0.001 \mathrm{~m}$-phosphate buffer once; 0.01 M-phosphate buffer three times; 0.1 M-phosphate buffer twice. The enzyme was usually eluted by $0.01 \mathrm{M}$ phosphate buffer, but sometimes part of the activity was also eluted by $0 \cdot 1 \mathrm{~m}$-phosphate buffer.

Chromatography on DEAE-cellulose or DEAE-Sephadex. A column ( $1 \mathrm{~cm} . \times 12 \mathrm{~cm}$.) of special high-capacity DEAEcellulose was washed with $0.01 \mathrm{M}$-phosphate buffer, $\mathrm{pH} 6 \cdot 8$, containing first EDTA (1mM) and then BAL (0.1mM). Either the redissolved and dialysed ammonium sulphate precipitate $(5 \mathrm{ml}$.) or the combined active enzyme solutions from calcium phosphate gel $(60-100 \mathrm{ml}$.) were applied to the column. The column was eluted with $0.01 \mathrm{~m}$-phosphate buffer containing BAL (0.1 mM), then with the same buffer containing successively $\mathrm{NaCl}(0 \cdot 1 \mathrm{M}), \mathrm{NaCl}(0 \cdot 15 \mathrm{M})$ and $\mathrm{NaCl}(0 \cdot 2 \mathrm{M})$. The column effluent was collected in fractions (5ml.) and $0.5 \mathrm{ml}$. samples were tested for protein and enzymic activity (in the regions of the protein peaks). The enzymically active column fractions were combined.

In a few experiments a column $(1 \mathrm{~cm} . \times 12 \mathrm{~cm}$.) of DEAE. Sephadex A-50 (medium grade) was used instead of DEAEcellulose. The column was washed with $0 \cdot 1 \mathrm{M}$-phosphate buffer containing first EDTA (1 $\mathrm{mm})$ and then BAL ( $0 \cdot 1 \mathrm{~mm})$. The enzyme eluted from calcium phosphate gel in $0.01-$ $0 \cdot 1 \mathrm{M}$-phosphate buffer (about $60 \mathrm{ml}$.) was applied to the column. The column was eluted with $0 \cdot 1 \mathrm{M}$-phosphate buffer containing BAL $(0 \cdot 1 \mathrm{mM})$, then with the same buffer containing successively $\mathrm{NaCl}(0.05 \mathrm{M}), \mathrm{NaCl}(0 \cdot 1 \mathrm{M})$ and $\mathrm{NaCl}$ $(0 \cdot 2 \mathrm{M})$. Fractions were collected and tested as before.

Concentration of enzyme solutions. The combined active fractions from DEAE-Sephadex columns were dialysed overnight in washed tubing against $0.01 \mathrm{M}$-phosphate buffer to remove $\mathrm{NaCl}$. Then the non-diffusible residue was dialysed (in the same tubing) against Carbowax 20M $[30 \%(\mathrm{w} / \mathrm{w})$ in $0.01 \mathrm{M}$-phosphate buffer containing BAL $(0 \cdot 1 \mathrm{~mm})]$ until the volume was reduced from about $100 \mathrm{ml}$. to about $10 \mathrm{ml}$. This solution was dialysed in a fresh bag 
against $0.01 \mathrm{M}$-phosphate buffer, to ensure the removal of diffusible materials that might not have already passed into the Carbowax solution. Next, the non-diffusible residue was concentrated (in the same dialysis tubing) to about $1 \mathrm{ml}$. by evaporation in a stream of air, then again dialysed against $0.01 \mathrm{M}$-phosphate buffer. This concentrated solution $(1 \cdot 7 \mathrm{mg}$. of protein $/ \mathrm{ml}$.) was used for ultracentrifuge, viscosity and electrophoretic studies, and its amino acid composition, after acid hydrolysis, was determined.

Measurement of enzymic activity. Diaminopimelate decarboxylase was usually measured manometrically in the Warburg apparatus at $37^{\circ}$, in an atmosphere of nitrogen, or in air when using the more purified preparations of enzyme. Each flask contained in the main compartment: enzyme solution (0.1-1.0 ml.); BAL (1mM); pyridoxal phosphate $(10 \mu \mathrm{g}$.$) ; all reagents were dissolved in 0.1 \mathrm{M}$ phosphate buffer, $\mathrm{pH} 6 \cdot 8$. The total volume of liquid in the flasks was adjusted to $2 \cdot 1 \mathrm{ml}$. with buffer, before the addition of substrate. After gassing the manometers and equilibrating, meso-diaminopimelic acid $(2 \mathrm{mg}$. in $0.4 \mathrm{ml}$. of 0.1 M-phosphate buffer) was tipped from the side arm. The initial rate of evolution of $\mathrm{CO}_{2}$ was measured without correction for retention of $\mathrm{CO}_{2}$ by the buffer. In some experiments $1.0 \mathrm{M}$-citric acid $(0.1 \mathrm{ml}$.) was tipped from the second side arm after gas evolution had ceased, to measure the total amount of $\mathrm{CO}_{2}$ produced during the decarboxylation. To test the enzymic activity of the orginal washed organisms, treatment with cetyltrimethylammonium bromide (White et al. 1964) was used.

Enzymic activity was also measured by following the rate of disappearance of diaminopimelate, by using a specific colorimetric method in which lysine does not interfere (Work, 1957). The same reagents as above were mixed in a $10 \mathrm{ml}$. conical flask, to give a total volume of $2.5 \mathrm{ml}$. of liquid in the flask. Either the enzyme solution or the diaminopimelic acid (dissolved in $0.4 \mathrm{ml}$. of buffer) was added after the other components had been mixed and equilibrated at $37^{\circ}$. The flasks were shaken and samples $(0.1 \mathrm{ml}$.) were removed at intervals and added to tubes containing acetic acid $(4 \mathrm{ml}$.) and water $(0 \cdot 4 \mathrm{ml}$.). When all the samples had been taken, $0.5 \mathrm{ml}$. of ninhydrin reagent (250 mg. of ninhydrin dissolved in $4 \mathrm{ml}$. of $0.6 \mathrm{M}$-phosphoric acid and $6 \mathrm{ml}$. of acetic acid) was added to each tube and the mixture was heated at $37^{\circ}$ for $90 \mathrm{~min}$. The extinctions of the mixtures were then measured at $440 \mathrm{~m} \mu$. Lysine (up to $250 \mu \mathrm{g}$.) did not interfere with the estimation of $50 \mu \mathrm{g}$. of diaminopimelate. The rate of disappearance of diaminopimelate was expressed as a rate of evolution of $\mathrm{CO}_{2}$, assuming that lmole of diaminopimelate gave 22.41. of $\mathrm{CO}_{2}$. The unit of enzymic activity was defined as the amount of enzyme that causes the evolution of $22 \cdot 4 \mu \mathrm{l}$. of $\mathrm{CO}_{2} / \mathrm{min}$. at $37^{\circ}$ from meso-diaminopimelate. Owing to retention of $\mathrm{CO}_{2}$ at $\mathrm{pH} 6 \cdot 8$, the unit as determined manometrically is larger by about one-third than that recommended by the Report of the Commission on Enzymes (1961, p. 8), namely the amount of enzyme that catalyses the transformation of $1 \mu \mathrm{mole}$ of substrate/min. Since an accurate correction for retention of $\mathrm{CO}_{2}$ cannot be made at $\mathrm{pH6} .8$ (Umbreit, Burris \& Stauffer, 1959), the colorimetric assay was used when it was necessary to measure true enzymic activities.

Other estimations. The dry wt. of washed suspensions of organisms in $0 \cdot 1 \mathrm{M}$-phosphate buffer was found by heating samples $\left(1.0 \mathrm{ml}\right.$.) to constant weight at $105^{\circ}$ and deducting the dry wt. of the buffer (16 mg.).
Protein was estimated by the method of Lowry, Rosebrough, Farr \& Randall (1951), with crystalline serum albumin (Armour Pharmaceutical Co., Eastbourne, Sussex) as a standard. Samples $(0.5 \mathrm{ml}$.) were treated with the reagents and the extinction at $750 \mathrm{~m} \mu$ of the mixture was measured. The amount of protein in the sample was read from the standard curve, assuming that the protein in the sample gave the same colour yield as the albumin. Similar results were obtained when protein concentrations were also estimated from the extinctions of solutions at 280 and $260 \mathrm{~m} \mu$ (Layne, 1957). The ratio of the extinctions at 280 and $260 \mathrm{~m} \mu$ was used for rough estimation of nucleic acids in protein solutions (Layne, 1957).

Examination of diaminopimelate decarboxylase in the ultracentrifuge. The purified concentrated enzyme, dissolved in $0.01 \mathrm{M}$-phosphate buffer, $\mathrm{pH} 6.8(0.85 \mathrm{mg}$. of protein in $0.5 \mathrm{ml}$. of buffer), was centrifuged at $59780 \mathrm{rev} . / \mathrm{min}$. at $19.3^{\circ}$ in the rotor of a Spinco model $\mathbf{E}$ analytical ultracentrifuge (Beckman Instruments Inc., Spinco Division, Palo Alto, Calif., U.S.A.). The sedimentation coefficient of the protein at $20^{\circ}$ was calculated, with a correction for the effect of the buffer salt. This work was kindly done by Dr J. P. Thornber.

Viscosity measurements. The viscosities of solutions of the purified concentrated enzyme in $0.01 \mathrm{M}$-phosphate buffer, pH6.8 (0.4-1.7 mg. of protein $/ \mathrm{ml}$.), were determined at $20.0^{\circ}$ by comparison of draining times with water and buffer in an Ostwald viscometer that required $2 \mathrm{ml}$. of liquid and had a draining time of 220 sec. with water. The specific viscosity, $\eta_{\mathrm{sp}}$, of the enzyme solution was calculated at each concentration tested. The intrinsic viscosity, $[\eta]$, of diaminopimelate decarboxylase was found from a graph of $\eta_{\text {sp. }}$ plotted against concentration, as described by Schachman (1957).

Electrophoresis of diaminopimelate decarboxylase. Electrophoresis was performed on $8 \%(w / v)$ polyacrylamide gel ( $1.66 \%$ cross-linking) in $0.03 \mathrm{~m}$-borate buffer, $\mathrm{pH} 8.9$, at room temperature. The apparatus of Davis (1962) was used, with a current of $8 \mathrm{~mA} /$ tube of gel, at $110 \mathrm{v}$, for $25 \mathrm{~min}$. The sample $(10 \mu \mathrm{l}$. containing $17 \mu \mathrm{g}$. of purified enzyme) was mixed with a little glycerol and applied to the gel by layering on its surface. After electrophoresis, the gel was stained with Amido Black 10B and then scanned in a densitometer (Chromoscan J297; Joyce, Loebl and Co. Ltd., Gateshead on Tyne, 11). This work was kindly done by Mr S. M. Ridley.

Amino acid analysis of diaminopimelate decarboxylase. A sample of the purified concentrated enzyme (1.0 mg. of protein) was hydrolysed in a sealed tube at $105^{\circ}$ for $18 \mathrm{hr}$. in $6 \mathrm{~N}-\mathrm{HCl}(2 \mathrm{ml}$.). The $\mathrm{HCl}$ was removed by repeated evaporation in vacuo over $\mathrm{NaOH}$, and the residue was taken up in $0.1 \mathrm{~m}$-citrate buffer, pH $2.2(2 \mathrm{ml}$.). The amino acid composition of this solution was determined by the method of Spackman, Stein \& Moore (1958), by using an EEL amino acid analyser (Evans Electroselenium Co. Ltd., Halstead, Essex). The apparatus was corrected for traces of ninhydrin-positive materials present in the buffers used to elute the columns. This work was kindly done by $\mathrm{Mr}$ L. Lester.

Chemicals. meso-Diaminopimelic acid was isolated from a mixture of meso- and LL-isomers by fractional crystallization from aqueous ethanol, as described by White et al. (1964). LL-Diaminopimelic acid was isolated from the mother liquor; after removal of most of the ethanol and 
addition of water (to give a concentration of about $10 \mathrm{mg}$. of diaminopimelic acid $/ \mathrm{ml}$.), $\mathrm{HCl}$ was added to make the solution about $1 \cdot 0 \mathrm{~N}$. Next, acetone was added until a slight permanent turbidity was produced, and the solution was left to crystallize. After 2-3 days the crop of LL-diaminopimelic acid hydrochloride was collected. No meso-isomer was present, as determined chromatographically (Hoare \& Work, 1957).

Pyridoxine phosphate and $\omega$-methylpyridoxamine phosphate were gifts from Professor E. E. Snell. Aminomalonic acid was a gift from Professor A. Neuberger, and bis-(Lalanyl)-meso-diaminopimelic acid was a gift from $\mathrm{Dr} E$. Bricas. D-Penicillamine was given by Dr D. L. Swallow. $S$-(2-Aminoethyl)cysteine hydrochloride was prepared from L-cysteine by the method of Cavallini, de Marco, Mondovi \& Azzone (1955). Calcium phosphate gel was prepared as described by Levin (1962). High-capacity DEAE-cellulose (ME29) was a gift from Dr S. E. Michael, for whom it was specially made by $W$. and $R$. Balston Ltd., Maidstone, Kent. The material had a capacity of about $5 \mu$ equiv./g. and was produced by the formation of cross-linkages between the cellulose molecules. Carbowax 20M (polyethylene glycol compound) was obtained from Union Carbide Chemicals Co., London, W.1. Other chemicals were of analyticalreagent grade where available.

\section{RESULTS}

Purification of diaminopimelate decarboxylase. Almost all the enzymic activity found in washed organisms treated with cetyltrimethylammonium bromide could be obtained in the soluble extract of organisms broken in the press. The extract was usually stored at $-15^{\circ}$; it could also be kept at $2^{\circ}$ for up to a month without much loss of activity. Steps in the purification of diaminopimelate decarboxylase from this extract are illustrated in Table 1. Except at the step of acetone fractionation, the enzyme was stable to storage for several days at $2^{\circ}$ at each stage.

A large amount of nucleic acid was present in the extract, which was very viscous. The nucleic acid was precipitated by protamine or streptomycin. but the amount of either reagent that caused the maximum precipitation also brought down diaminopimelate decarboxylase. Consequently, protamine and streptomycin were used together, each at a concentration just lower than that causing precipitation of the enzyme. This procedure removed the greatest amount of nucleic acid without appreciable loss of enzyme from solution.

The fractionation with acetone was somewhat variable, and small trials were made before treating a large batch of enzyme. In some batches the enzyme was precipitated between $30 \%$ and $45 \%$ $(\mathrm{v} / \mathrm{v})$ rather than between $40 \%$ and $50 \%(\mathrm{v} / \mathrm{v})$ of acetone. Acetone fractionation gave fairly good recoveries of enzymic activity, but the redissolved enzyme was not stable at $2^{\circ}$, about half its activity being lost on storage overnight. The next step, precipitation with ammonium sulphate, was always done immediately after the acetone fractionation.

Hoare \& Work (1955) reported that diamino-

Table 1. Steps in the purification of diaminopimelate decarboxylase from $\mathbf{E}$. coli

Details of each step are given in the Methods section. Enzymic activity was measured manometrically. The purification from two separate batches of extract (A and B) is illustrated. As far as step 4, the same treatments were used for both, but steps 2 and 3 with extract $B$ have been omitted for brevity.

\begin{tabular}{|c|c|c|c|c|c|c|c|c|}
\hline & $\begin{array}{l}\text { Total } \\
\text { vol.* } \\
\text { (ml.) }\end{array}$ & $\begin{array}{l}\text { Total } \\
\text { units* }\end{array}$ & Units/ml. & $\begin{array}{l}\text { Protein } \\
(\mathrm{mg} . / \mathrm{ml} .)\end{array}$ & $\begin{array}{c}\text { Units/mg. } \\
\text { of } \\
\text { protein }\end{array}$ & $\begin{array}{c}\text { Recovery } \\
(\%)\end{array}$ & $\begin{array}{l}\text { Puri- } \\
\text { fication } \\
\text { factor }\end{array}$ & $\begin{array}{l}\text { Percentage of } \\
\text { extinction at } \\
280 \mathrm{~m} \mu \text { due to } \\
\text { nucleic acids }\end{array}$ \\
\hline 1. Extract A & 125 & 101 & 0.81 & 23 & 0.035 & & & $>20$ \\
\hline $\begin{array}{l}\text { 2. Supernatant after pruja- } \\
\text { mine and streptomycin }\end{array}$ & 126 & 91 & 0.72 & 17 & 0.042 & 90 & 1.2 & 5.8 \\
\hline $\begin{array}{l}\text { 3. } 40-50 \% \text { Acetone precipi- } \\
\text { tate }\end{array}$ & 120 & 60 & 0.50 & $3 \cdot 5$ & $0 \cdot 14$ & 60 & $4 \cdot 0$ & $5 \cdot 4$ \\
\hline $\begin{array}{l}\text { 4. } 50 \% \text { Satd. ammonium sul- } \\
\text { phate precipitate }\end{array}$ & 60 & 60 & 1.00 & $1 \cdot 0$ & 1.00 & 60 & 29 & $1 \cdot 8$ \\
\hline $\begin{array}{l}\text { 5. DEAE-cellulose eluate } \\
(0 \cdot 15 \mathrm{M}-\mathrm{NaCl})\end{array}$ & 200 & 30 & $0 \cdot 15$ & 0.020 & $7 \cdot 5$ & 30 & 210 & 1.0 \\
\hline 1. Extract B & 110 & 121 & $1 \cdot 1$ & 25 & 0.044 & & & - \\
\hline $\begin{array}{l}\text { 4. } 50 \% \text { Satd. ammonium sul- } \\
\text { phate precipitate }\end{array}$ & 50 & 57 & $1 \cdot 15$ & 0.70 & 1.6 & 47 & 37 & - \\
\hline $\begin{array}{l}\text { 5. Calcium phosphate gel } \\
\text { eluate }\end{array}$ & 90 & 23 & 0.25 & 0.051 & $5 \cdot 0$ & 19 & 110 & - \\
\hline 6. DEAE-cellulose eluate & 44 & 12 & 0.27 & 0.030 & $9 \cdot 0$ & 10 & 200 & $1 \cdot 0$ \\
\hline
\end{tabular}

* Corrected to allow for material removed for testing, and to adjust for the fact that not all the material obtained at one step was usually carried on to the next. 
pimelate decarboxylase was inhibited by ammonium sulphate and other salts. Consequently, in the first experiments, ammonium sulphate was recrystallized from ImM-EDTA in water before being used to precipitate the enzyme. Later it was found that this recrystallization was unnecessary. Diaminopimelate decarboxylase was precipitated between $40 \%$ and $50 \%$ saturation of the solution with ammonium sulphate; very little protein was precipitated by less than $40 \%$ saturation. Ammonium sulphate had to be removed by dialysis if the redissolved enzyme were to be adsorbed on DEAE-cellulose. This dialysis was not necessary when calcium phosphate gel was used, but then the enzyme had to be redissolved in 0.001M-phosphate buffer for it to be adsorbed by the gel.

Treatment with calcium phosphate was not always used because of the difficulty in obtaining reproducible results. The gel did not always adsorb the enzyme, and, when adsorbed, the enzyme was not always eluted by the same concentration of phosphate buffer. The recovery of enzymic activity from the gel was only about $50 \%$.

Diaminopimelate decarboxylase in $0.01 \mathrm{M}$-phos-

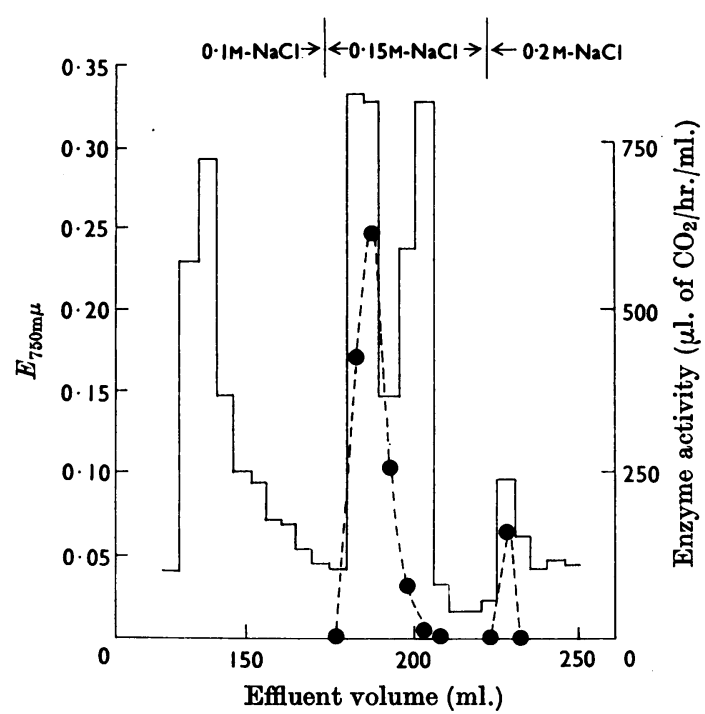

Fig. 1. Elution of diaminopimelate decarboxylase from high-capacity DEAE-cellulose. On a column $(1 \mathrm{~cm} . \times 14 \mathrm{~cm}$.) was applied $15 \mathrm{ml}$. of enzyme solution $(50 \mu \mathrm{g}$. of protein $/ \mathrm{ml}$.) that had been purified as far as elution from calcium phosphate gel (see the Methods section). The column was eluted in steps with increasing concentrations of $\mathrm{NaCl}$ in $0.01 \mathrm{M}$ phosphate buffer, pH6.8, containing BAL (0.1 mM). Fractions $(5 \mathrm{ml}$.) were collected and samples $(0.5 \mathrm{ml}$.) were tested for protein(-)and enzymic activity (๑). The extinction of the coloured reaction product at $750 \mathrm{~m} \mu$ was used to measure protein (see the Methods section). phate buffer was eluted from DEAE-cellulose by $0.15 \mathrm{M}$-sodium chloride but not by $0.1 \mathrm{M}$-sodium chloride (Fig. 1). Some enzyme was also usually eluted by $0.2 \mathrm{M}$-sodium chloride but not by higher concentrations. The final purification obtained after the DEAE-cellulose treatment was only slightly increased by preliminary treatment of the enzyme with calcium phosphate gel. However, a larger quantity of enzyme could be put on the column at one time when it had first been purified by gel treatment. No higher purification of the enzyme was obtained from columns when gradient elution with sodium chloride was used. The recovery of enzymic activity from DEAE-cellulose was only $50-60 \%$, and no improvement in yield resulted from various modifications of technique, such as preliminary passage of buffers through a column of Chelex-100 resin (to remove bivalent cations), or recrystallization of sodium chloride from ImM-EDTA in water. Also, various compounds other than BAL were no more successful as protective agents in the buffers : EDTA ( $0 \cdot 1 \mathrm{mM})$; pyridoxal phosphate (lmg./1.), as suggested by Sutton \& King (1962); or Triton X-100 (0.001\%), as suggested by Tsuboi \& Hudson (1955). The enzyme was put on the column as a mercury derivative (Antia, Hoare \& Work, 1957) and eluted with buffers containing no BAL or EDTA, but this did not improve the recovery. Unsuccessful attempts were also made to elute the enzyme from a column with its substrate, diaminopimelic acid (1mg. of meso- and LL-isomers/1.) as suggested by Pogell (1962). Lower recoveries of enzymic activity were obtained when larger columns of DEAE-cellulose were used, and ordinary DEAE-cellulose gave a lower recovery than the high-capacity material. Epichlorohydrin triethanolamine (ECTEOLA)-cellulose resembled DEAE-cellulose in the elution pattern of protein and enzyme, but recovery of enzymic activity was lower. When CM-cellulose was used, none of the protein applied at $\mathrm{pH} 6.8$ was retained on the column. DEAE-Sephadex was used only in some of the later experiments, and has not been very thoroughly examined. The recovery of enzymic activity was a little better than from high-capacity DEAE-cellulose, and the degree of purification was about the same with both materials.

Almost all the enzymic activity could be recovered after passage of solutions through ordinary Sephadex of various grades, and Sephadex G-25 columns were sometimes used instead of dialysis. An attempt was made to purify the enzyme (at the stage of the redissolved precipitate from the ammonium sulphate fractionation) by passage through a column of Sephadex G-200. However, all the protein came through the column as one peak, which coincided with diaminopimelate-decarboxylase activity.

Properties of the purified enzyme. The purified 
enzyme gave only a single peak in the ultracentrifuge, and the material in the peak had a sedimentation coefficient, $S_{20, w}$ of $5 \cdot 4 \mathrm{~s}$. The intrinsic viscosity was $0.215 \mathrm{dl}$./g. The mol.wt. of diaminopimelate decarboxylase was calculated to be about 200000, from the formula (Schachman, 1957):

$$
\text { Mol.wt. }=\frac{4690\left(S_{20, w}\right)^{3 / 2}[\eta]^{1 / 2}}{(1-\bar{v} \rho)^{3 / 2}}
$$

where $\bar{v}$, the partial specific volume of the protein, was assumed to be $0.73 \mathrm{ml} . / \mathrm{g}$., and $\rho$, the density of the solution, was taken as $1.00 \mathrm{~g} . / \mathrm{ml}$.

The most highly purified preparation of the enzyme had an activity of $10 \mathrm{units} / \mathrm{mg}$. of protein, when assayed by the colorimetric method. Therefore the catalytic constant of the enzyme, taking the mol.wt. to be 200000 , was $2000 \mathrm{~mol}$. of substrate decomposed $/ \mathrm{min} . / \mathrm{mol}$. of enzyme, at $37^{\circ}$.

Washed organisms, treated with cetyltrimethylammonium bromide, had an enzymic activity of about 0.025 unit $/ \mathrm{mg}$. dry wt. The organisms therefore appear to contain $2 \cdot 5 \mu \mathrm{g}$. of enzyme/mg. dry wt., or 2000 mol. of enzyme/organism (lmg. dry wt. corresponds to approx. $4 \times 10^{9}$ organisms).

All the protein in the purified enzyme moved

Table 2. Analysis of amino acids in an acid hydrolysate of diaminopimelate decarboxylase

Enzyme purified as far as elution from DEAE-Sephadex (see the Methods section) and concentrated to $1 \mathrm{ml}$. containing $1 \mathrm{mg}$. of protein was mixed with conc. $\mathrm{HCl}(1 \mathrm{ml}$.) and heated at $105^{\circ}$ for $18 \mathrm{hr}$. in a sealed tube. The $\mathrm{HCl}$ was removed by repeated evaporation over $\mathrm{NaOH}$ in vacuo, and the residue was taken up in $2 \mathrm{ml}$. of $0.1 \mathrm{M}$-citrate buffer, pH 2.2. The amino acid composition of this hydrolysate was determined (see the Methods section).

Amino acid content

$\begin{array}{ccc}\text { Amino } & \text { ( } \mu \text { mole/ml. of } & \text { (moles } / 200000 \mathrm{~g} . \\ \text { ocid } & \text { hydrolysate) } & 150 \\ \text { Asp } & 0 \cdot 364 & 67 \\ \text { Thr } & 0 \cdot 167 & 68 \\ \text { Ser } & 0 \cdot 169 & 200 \\ \text { Glu } & 0 \cdot 502 & 68 \\ \text { Pro } & 0 \cdot 169 & 160 \\ \text { Gly } & 0 \cdot 404 & 170 \\ \text { Ala } & 0 \cdot 424 & 110 \\ \text { Val } & 0 \cdot 286 & 25 \\ \text { Met } & 0 \cdot 063 & 88 \\ \text { Ile } & 0 \cdot 220 & 170 \\ \text { Leu } & 0 \cdot 432 & 41 \\ \text { Tyr } & 0 \cdot 102 & 60 \\ \text { Phe } & 0 \cdot 150 & 33 \\ \text { Lys } & 0.083 & 45 \\ \text { His } & 0 \cdot 113 & 66 \\ \text { Arg } & 0 \cdot 165 & 410 \\ \text { NH } & 1 \cdot 031 & \end{array}$

towards the cathode on electrophoresis at $\mathrm{pH} 8.9$ on polyacrylamide gel. There was one major component, of lowest mobility, and three other minor peaks. The relative areas under each peak (determined by integration in the Chromoscan apparatus) were $132,38,10$ and 4 , in order of increasing mobility. Which of the peaks represented diaminopimelate decarboxylase has not been determined.

The composition of the mixture of amino acids produced by hydrolysis of diaminopimelate decarboxylase in $6 \mathrm{~N}$-hydrochloric acid is shown in Table 2. Under these conditions of hydrolysis it is likely that tryptophan, cysteine, cystine and some methionine were destroyed; the amount of purified enzyme that was available was insufficient to make separate analyses for these amino acids.

Enzymic activity was measured at various $\mathbf{p H}$ values, the colorimetric method being used to avoid errors due to carbon dioxide retention (Fig. 2). The optimum pH was $6 \cdot 7-6 \cdot 8$. The purified enzyme could be kept at this $\mathrm{pH}$ at $2^{\circ}$ (in the presence of $0.1 \mathrm{~mm}$-BAL) for several weeks without much loss of activity. It was stable overnight at $2^{\circ}$ between pH 6.0 and $7 \cdot 5$.

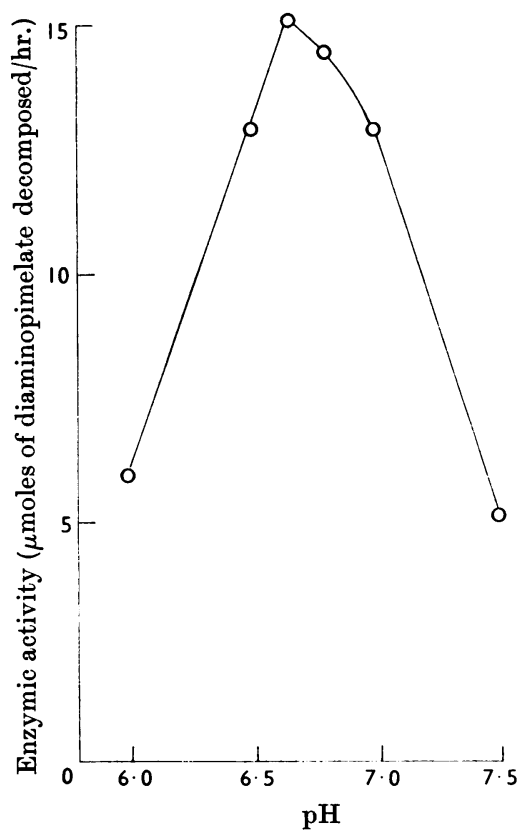

Fig. 2. Activity of diaminopimelate decarboxylase at different $\mathrm{pH}$ values. The rate of disappearance of mesodiaminopimelic acid was measured by the colorimetric method, in 0.1 M-phosphate buffer at various $\mathrm{pH}$ values. A constant amount of enzyme (20 $\mu \mathrm{g}$.) was used throughout (purified as far as elution from DEAE-cellulose and concentration; see the Methods section). 


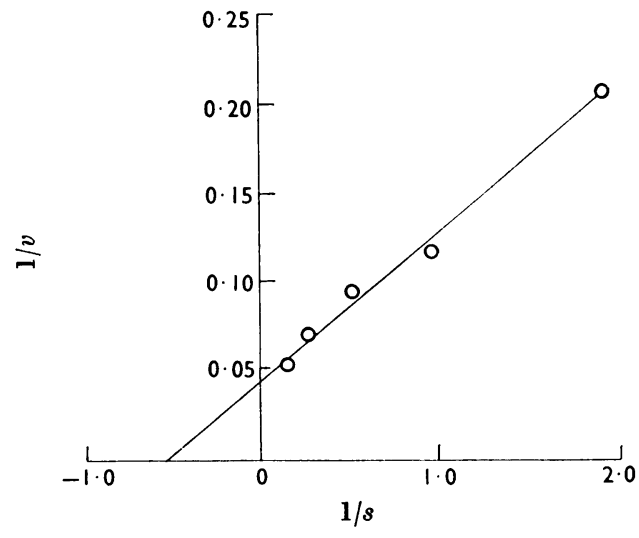

Fig. 3. Effect of substrate concentration on rate of enzymic decarboxylation of meso-diaminopimelic acid. The initial rate of disappearance of meso-diaminopimelic acid ( $v$, $\mu$ moles decomposed $/ \mathrm{hr}$.) at various concentrations ( $s$, $\mu$ moles $/ \mathrm{ml}$.) was determined by the colorimetric method, with diaminopimelate decarboxylase $(25 \mu \mathrm{g}$.) that had been purified as far as elution from DEAE-cellulose and concentration (see the Methods section). The straight line was calculated by the method of least squares.

The initial rate of decarboxylation was measured with various concentrations of meso-diaminopimelic acid, by using the colorimetric method. The results were plotted by the method of Lineweaver \& Burk (1934) and the Michaelis constant of diaminopimelate decarboxylase was found to be $0.17 \mathrm{~mm}$ (Fig. 3). Over at least a tenfold range of concentration $(10-100 \mu \mathrm{g}$. of protein) the rate of decarboxylation (measured colorimetrically) was proportional to the amount of enzyme.

Enzymic activity was measured manometrically at several temperatures between $25^{\circ}$ and $45^{\circ}$. The relative rates of decarboxylation at $25^{\circ}, 37^{\circ}$ and $45^{\circ}$ were $0 \cdot 17: 1 \cdot 0: 1 \cdot 6$. The logarithm of the initial rate of reaction was plotted against the reciprocal of the absolute temperature (Fig. 4). From the slope of this curve at $37^{\circ}$ the energy of activation of the decarboxylation at that temperature was calculated to be $18 \mathrm{kcal} . / \mathrm{mole}$ (Dixon \& Webb, 1958).

Specificity, and assay of meso-diaminopimelic acid. Only the meso-isomer of diaminopimelic acid is decarboxylated by the enzyme, and the reaction continues until decarboxylation (to lysine) is complete. No other substrate for the enzyme has been found (Hoare \& Work, 1955). The enzyme has been used successfully to estimate mesodiaminopimelate in specially prepared mixtures of meso- and LL-isomers. The decarboxylation is allowed to proceed to completion, and then either the total carbon dioxide evolved is measured, or the amount of diaminopimelic acid remaining is

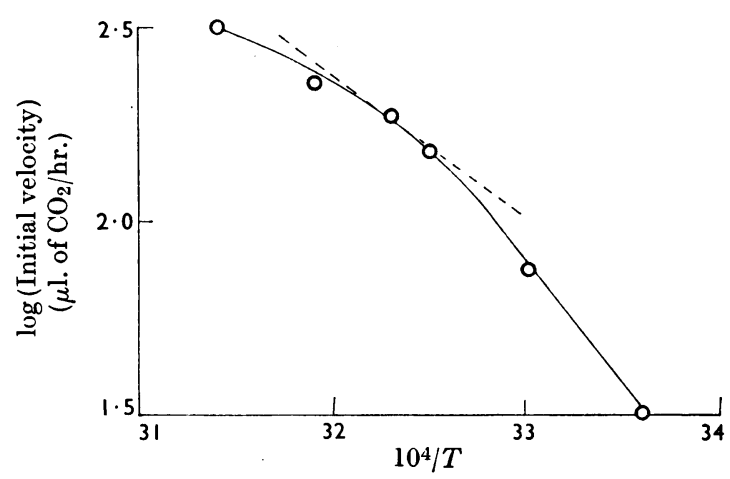

Fig. 4. Activity of diaminopimelate decarboxylase at various temperatures. The initial rate of decarboxylation was measured at various temperatures by the manometric method, with enzyme $(20 \mu \mathrm{g}$. throughout) that had been purified as far as elution from DEAE-cellulose (see the Methods section). The broken line is the slope of the curve at $37^{\circ}$.

determined colorimetrically and subtracted from that present initially to give the amount of mesoisomer. Since the enzyme is not inhibited by heavy metal ions or thiol-binding reagents when BAL $(1 \mathrm{~mm})$ is present as an activator, this method may be used to assay for meso-isomer. Thus commercial diaminopimelic acid (Chas. Pfizer and Co. Inc., Groton, Conn., U.S.A.), which is a mixture of meso- and LL-isomers containing $20 \%$ of the LL-form by polarimetry (Work, Birnbaum, Winitz \& Greenstein, 1955), was found manometrically to contain $81 \%$ of the meso-isomer. However, the enzyme is still inhibited by some amino acids (see below), and this may limit its usefulness in assays.

Cofactors and activators. Pyridoxal phosphate was required as a cofactor; even the starting extract or the washed intact organisms had no enzymic activity in the absence of this compound. The amount of pyridoxal phosphate needed for full enzymic activity was ten times as high $(0.16 \mathrm{~mm})$ in the washed organisms treated with cetyltrimethylammonium bromide as in the extract prepared from them: presumably, the organisms are not very permeable to pyridoxal phosphate. Of a number of derivatives of pyridoxine that were tested as cofactors, only pyridoxal phosphate was active (Table 3). Enzymic activity was not increased by pyruvic acid or $\alpha$-oxoglutaric acid (1mM) in the absence or presence of pyridoxal phosphate, at optimum $(16 \mu \mathrm{M})$ or sub-optimum $(3.2 \mu \mathrm{M})$ concentrations.

The attachment between enzyme and cofactor appears to be weak, because pyridoxal phosphate $(50 \mu \mathrm{g}$.$) could be removed from the enzyme (100 \mu \mathrm{g}$. when a mixture of the two $(5 \mathrm{ml}$.) was dialysed overnight at $2^{\circ}$ against $250 \mathrm{ml}$. of $0.01 \mathrm{M}$-phosphate 
Table 3. Activity of various derivatives of pyridoxine as cofactors for diaminopimelate decarboxylase

Enzymic activity was measured manometrically with various compounds as cofactors, and BAL (1mM) as activator. The enzyme had been purified as far as elution from DEAE-cellulose (see the Methods section).

\begin{tabular}{|c|c|c|}
\hline Compound & $\begin{array}{c}\text { Amount/ } \\
\text { Warburg flask } \\
(\mu g .)\end{array}$ & $\begin{array}{c}\text { Enzymic activity } \\
\text { (\% of rate with } \\
100 \mu \mathrm{g} . \text { of } \\
\text { pyridoxal } \\
\text { phosphate/flask) }\end{array}$ \\
\hline 一 & 一 & 0 \\
\hline Pyridoxal phosphate & 100 & 100 \\
\hline & 10 & 100 \\
\hline & 3 & 91 \\
\hline & 1 & 43 \\
\hline Pyridoxal & 100 & 0 \\
\hline Pyridoxine phosphate & 100 & 0 \\
\hline Pyridoxine & 100 & 0 \\
\hline Pyridoxamine phosphate & 100 & 0 \\
\hline $\begin{array}{l}\text { 4-Deoxypyridoxal phos- } \\
\text { phate }\end{array}$ & $00^{*}$ & 0 \\
\hline $\begin{array}{l}\text { 4-Deoxypyridoxine } \\
\text { phosphate }\end{array}$ & vo* & 0 \\
\hline $\begin{array}{l}\omega \text {-Methylpyridoxamine } \\
\text { phosphate }\end{array}$ & $100 *$ & 0 \\
\hline
\end{tabular}

* No inhibition of enzymic activity in the presence of pyridoxal phosphate ( $1 \mu \mathrm{g}$./flask). These three compounds were tested with enzyme purified only as far as ammonium sulphate fractionation.

buffer, pH 6.8, containing BAL $(0 \cdot 1 \mathrm{~mm})$. The dialysed enzyme had no activity until more pyridoxal phosphate was added; the activity then became the same as that of control mixtures of enzyme and pyridoxal phosphate, which had not been dialysed and which retained $75 \%$ of their activity after keeping overnight at $2^{\circ}$. The enzyme lost activity more quickly at $2^{\circ}$ when pyridoxal phosphate was added than when the cofactor was absent.

The activity of diaminopimelate decarboxylase in the original extract was not increased by the addition of BAL during assay. However, as the enzyme was purified, a requirement for BAL became increasingly apparent, and the more highly purified enzyme preparations had no activity in the absence of BAL (Table 4). Several other thiol compounds were tested as activators, but none was as effective as BAL.

Inhibitors. Various compounds have been tested as inhibitors of the enzyme, always with BAL and pyridoxal phosphate present (Table 5). Under these conditions, heavy-metal ions and $p$-chloromercuribenzoate were not inhibitors, although they had been found to inhibit strongly the crude enzyme in the absence of BAL (Dewey et al. 1954).
Table 4. Activation of diaminopimelate decarboxylase by various compounds

The activity of diaminopimelate decarboxylase was measured manometrically with various compounds as activators, and with pyridoxal phosphate (10 $\mu \mathrm{g}$./Warburg flask) present throughout. The enzyme had been purified as far as elution from DEAE-cellulose (see the Methods section).

\begin{tabular}{|c|c|c|}
\hline Compound & $\begin{array}{l}\text { Concn. } \\
\text { (mM) }\end{array}$ & $\begin{array}{l}\text { Enzymic activity } \\
\text { (\% of rate with } \\
\text { lmM-BAL) }\end{array}$ \\
\hline - & - & 0 \\
\hline \multirow[t]{6}{*}{ BAL } & 0.01 & 6 \\
\hline & $0 \cdot 03$ & 42 \\
\hline & $0 \cdot 1$ & 58 \\
\hline & $0 \cdot 3$ & 85 \\
\hline & $1 \cdot 0$ & 100 \\
\hline & 10 & 107 \\
\hline EDTA & $1 \cdot 0$ & 0 \\
\hline $\begin{array}{l}\text { EDTA+L- } \\
\text { cysteine }\end{array}$ & $1 \cdot 0$ (each compound $)$ & 17 \\
\hline $\begin{array}{l}\text { EDTA+ sodium } \\
\text { sulphite }\end{array}$ & $1 \cdot 0$ (each compound $)$ & 0 \\
\hline $\begin{array}{l}\text { 2-Mercapto- } \\
\text { ethanol }\end{array}$ & $1 \cdot 0$ & 43 \\
\hline Glutathione & $1 \cdot 0$ & 16 \\
\hline Ascorbic acid & $1 \cdot 0$ & 6 \\
\hline Sodium pyruvate & $1 \cdot 0$ & 0 \\
\hline
\end{tabular}

Of a number of compounds that may be regarded as structural analogues of diaminopimelic acid, cystine, glutamic acid (Dewey et al. 1954), diaminopropionic acid and $\alpha$-aminopimelic acid (K. Tattersall, personal communication) were inhibitors when present in excess of the substrate concentration: diaminopropionic acid was the most effective inhibitor. Lysine and its analogue aminoethylcysteine caused $50 \%$ inhibition when present at concentrations ten times that of the substrate. The effect of aminoethylcysteine (but not of lysine) was prevented by increased amounts of pyridoxal phosphate, suggesting that the inhibition may have been due to removal of pyridoxal phosphate, perhaps by Schiff base formation. ATP had no effect on enzymic activity although it had been found to be an inhibitor of crude preparations (C. Gilvarg, personal communication). A striking inhibition was caused by penicillamine, and was prevented by increased concentrations of pyridoxal phosphate. Penicillamine has been reported to inhibit decarboxylation of amino acids through formation of a thiazolidinecarboxylic acid derivative from pyridoxal phosphate (Mardashev, 1963). Other compounds known to inhibit some enzymes that contain pyridoxal phosphate (iodoacetic acid, cycloserine and 6-amino-5-hydroxymethyl-2 methylpyrimidine phosphate) did not inhibit diaminopimelate decarboxylase at the concentrations tested. 
Table 5. Inhibition of diaminopimelate decarboxylase by various compounds

Enzymic activity was measured manometrically; the inhibitor, enzyme, BAL (1mM) and pyridoxal phosphate $(16 \mu \mathrm{M})$ were mixed before addition of the substrate (mesodiaminopimelic acid, 4.0 mM throughout). Various batches of enzyme were used, purified at least as far as fractionation with ammonium sulphate (see the Methods section).

\section{Inhibition} of rate of enzymic

\section{Compound}

\section{Conen.}

(mM)

$0 \cdot 1$

$0 \cdot 1$

$0 \cdot 1$

40

40

$4 \cdot 0$

$8 \cdot 0$

20

6.0

17

4. 0

$4 \cdot 8$

40

40

4.0

$1 \cdot 0$

$1 \cdot 0$

$0 \cdot 1$

0.4

$0 \cdot 2$

4. 0 difference in the solubility of the enzyme from the two sources.

The main difficulty that was encountered during the purification was the relatively low recovery of activity when the enzyme was eluted from solids on which it had been adsorbed. Only about $30-50 \%$ of the enzyme adsorbed on DEAE- or ECTEOLA-cellulose columns, or calcium phosphate gel, could be recovered. Generally, poorer recoveries were obtained from larger columns, and this limited the amount of enzyme that could be purified at one time. Even when the same small column was used several times, the recovery of enzyme varied considerably in different experiments. The most consistent and highest recoveries (about 60\%) were obtained from the special high-capacity DEAE-cellulose and from DEAE-Sephadex. It seems unlikely that the loss of enzymic activity is due to inhibitors introduced from the cellulose, which had been very thoroughly washed; further, the enzyme when activated by BAL is not sensitive to metal ions. More probably, adsorption causes changes in the tertiary structure of the enzyme molecule that may decrease its activity. Very little enzymic activity was lost when solutions were passed through columns of materials, such as CMcellulose or ordinary Sephadex, that do not adsorb the enzyme.

At the stage where purification was stopped, the enzyme gave only one peak in the ultracentrifuge, and showed one main component on electrophoresis. Both of these studies were of a limited nature, but the electrophoresis showed that the purified enzyme is not a homogeneous protein. Because of the relatively low enzymic activity present initially in the organisms (about 0.03 unit $/ \mathrm{mg}$. dry wt.), the yield of the most highly purified enzyme was very small, and attempts at further purification did not seem worth while.

The results for the amino acid composition of diaminopimelate decarboxylase are incomplete, through the absence of values for cystine, cysteine and tryptophan, which are destroyed under the conditions used for hydrolysis; probably some methionine would also be destroyed. The sum of the amounts of the separate amino acid residues is in close agreement with the amount of enzyme protein from which the amino acids are derived. However, this sum must be decreased by $14 \%$ to correct for the water liberated by condensations between the amino acids on the formation of peptide bonds.

The fact that diaminopimelate decarboxylase was bound by basic cellulose derivatives but not by acidic derivatives at pH 6.8 suggested that the enzyme is an acidic protein. The amino acid analysis confirmed that the enzyme contained a considerable excess of acidic amino acids over basic amino 
acids. The amount of ammonia present in the hydrolysate was such that all the carboxylic acid groups of aspartic acid and glutamic acid could be in the amide form. Probably, however, this was not the case, because much of the ammonia may have been produced by breakdown of labile amino acids during hydrolysis of the protein.

The initial extract was free of lysine-decarboxylase activity ; diaminopimelate epimerase was almost completely removed through co-precipitation with the nucleic acids, and after ammonium sulphate fractionation no epimerase remained. The final purified diaminopimelate decarboxylase was specific for meso-diaminopimelic acid; no carbon dioxide was evolved from any other compound that has been tested, in confirmation of results of Hoare \& Work (1955). The Michaelis constant, $1.7 \mathrm{~mm}$, is lower than was estimated roughly by Dewey et al. (1954) with the enzyme from $A$. aerogenes $(2 \cdot 8 \mathrm{mM})$. These workers were not able to correct for carbon dioxide retention, and the diaminopimelic acid used as substrate may not have been pure meso-isomer. Both of these factors would tend to give a high value for the Michaelis constant. The $\mathrm{pH}$ optimum, 6.7-6.8 for purified enzyme from $E$. coli, is the same as that found by Dewey et al. (1954) with the enzyme from $A$. aerogenes.

The absolute requirement of diaminopimelate decarboxylase for pyridoxal phosphate as a cofactor was surprising, as previously no completely inactive purified apoenzyme preparation had been obtained (Work, 1962). $\alpha$-Oxo acids did not replace pyridoxal phosphate nor increase the activity of sub-optimum concentrations of the cofactor.

These findings differ somewhat from those of Meadow \& Work (1958) with the unfractionated diaminopimelate decarboxylase in acetone-dried Bacillus sphaericus asporogenous. From this organism a sub-strain was developed that decarboxylated diaminopimelic acid only in the presence of added pyridoxal phosphate. However, not only pyridoxal phosphate, but all the other derivatives of pyridoxine that were tested, had activity as cofactors, with the phosphorylated derivatives the more active. Pyruvic acid, oxaloacetic acid and $\alpha$-oxoglutaric acid all stimulated the rate of decarboxylation in the absence of pyridoxal phosphate, and augmented the rate when pyridoxamine phosphate or sub-optimum amounts of pyridoxal phosphate were used. In these studies the enzyme had not been purified, and the various derivatives of pyridoxine might have been converted into pyridoxal phosphate by other enzymes that were also present.

We are grateful to Dr G. M. Shull of Chas. Pfizer and Co. Inc., U.S.A., for gifts of diaminopimelic acid. We also thank Dr E. Bricas, Dr S. E. Michael, Professor A. Neuberger, Professor E. E. Snell and Dr D. L. Swallow, who have sent us chemicals. Mr R. F. Denman very kindly grew organisms in a continuous-culture apparatus that he had designed. Mr M. J. Jackson has given valuable technical assistance in part of this work. Mr L. Lester, Mr S. M. Ridley and Dr J. P. Thornber carried out various determinations, for which we are grateful. We wish particularly to thank Dr Elizabeth Work for much helpful advice and encouragement.

\section{REFERENCES}

Antia, M., Hoare, D. S. \& Work, E. (1957). Biochem. J. 65, 448.

Cavallini, D., de Marco, C., Mondovì, B. \& Azzone, G. F. (1955). Experientia, 11, 61.

Davis, B. D. \& Mingioli, E. S. (1950). J. Bact. 60, 17.

Davis, B. J. (1962). Disc electrophoresis. Part 2: Materials and Methods. Rochester, N.Y.: Distillation Products Industries (Division of Eastman-Kodak Co.).

Dewey, D. L., Hoare, D. S. \& Work, E. (1954). Biochem. J. $58,523$.

Dixon, M. \& Webb, E. C. (1958). Enzymes, p. 156. London: Longmans, Green and Co.

Hoare, D. S. \& Work, E. (1955). Biochem. J. 61, 562.

Hoare, D. S. \& Work, E. (1957). Biochem. J. 65, 441.

Layne, E. (1957). In Methods in Enzymology, vol. 3, p. 447. Ed. by Colowick, S. P. \& Kaplan, N. O. New York: Academic Press Inc.

Levin, O. (1962). In Methods in Enzymology, vol. 5, p. 27. Ed. by Colowick, S. P. \& Kaplan, N. O. New York: Academic Press Inc.

Lineweaver, H. \& Burk, D. (1934). J. Amer. chem. Soc. $56,658$.

Lowry, O. H., Rosebrough, N. J., Farr, A. L. \& Randall, R. J. (1951). J. biol. Chem. 193, 265.

Mardashev, S. R. (1963). In Chemical and Biological Aspects of Pyridoxal Catalysis, p. 277. Ed. by Snell, E. E., Fasella, P. M., Braunstein, A. \& Rossi Fanelli, A. Oxford: Pergamon Press Ltd.

Meadow, P. \& Work, E. (1958). Biochim. biophys. Acta, 29, 180.

Milner, H. W., Lawrence, N. S. \& French, C. S. (1950). Science, 111, 633.

Pogell, B. M. (1962). Biochem. biophys. Res. Commun. 7, 225.

Schachman, H. K. (1957). In Methods in Enzymology, vol. 4, p. 32. Ed. by Colowick, S. P. \& Kaplan, N. O. New York: Academic Press Inc.

Spackman, D. H., Stein, W. H. \& Moore, S. (1958). Analyt. Chem. 30, 1190.

Sutton, C. R., \& King, H. K. (1962). Arch. Biochem. Biophys. 96, 360.

Tsuboi, K. K. \& Hudson, P. B. (1955). Arch. Biochem. Biophys. 55, 191.

Umbreit, W. W., Burris, R. H. \& Stauffer, J. F. (1959). Manometric Techniques, p. 30. Minneapolis: Burgess Publishing Co.

White, P. J., Kelly, B., Suffling, A. \& Work, E. (1964). Biochem. J. 91, 600.

Work, E. (1957). Biochem. J. 67, 416.

Work, E. (1962). In Methods in Enzymology, vol. 5, p. 864. Ed. by Colowick, S. P. \& Kaplan, N. O. New York: Academic Press Inc.

Work, E., Birnbaum, S. M., Winitz, M. \& Greenstein, J. P. (1955). J. Amer. chem. Soc. 77, 1916. 